http://dx.doi.org/10.15361/1984-5529.2016v44n1p5-13

\title{
Adsorption isotherms and vaporization latent heat of malagueta pepper seeds
}

\author{
Isotermas de adsorção e calor latente de vaporização das sementes de \\ pimenta malagueta
}

\section{Hellismar Wakson da SILVA ${ }^{1}$; Renato Souza RODOVALHO ${ }^{2}$}

${ }^{1}$ Engenheiro Agrônomo, Mestrando em Agronomia/Fitotecnia, Universidade Federal de Lavras - UFLA, Lavras-MG, e-mail: waksonhellismar@gmail.com.

${ }^{2}$ Autor para correspondência. Doutor em Agronomia, IF Goiano - Câmpus Ceres, cx. P. 51, CEP: 76300-000. Ceres GO, e-mail: renato.rodovalho@ifgoiano.edu.br

\section{Recebido em: 09-03-2015; Aceito em: 17-08-2015}

\begin{abstract}
The aim of this study was to determine and model malagueta pepper seeds adsorption isotherms, as well as to estimate the vaporization latent heat released during adsorption process. Hygroscopic balance moisture contents were determined by static method, using six saline solutions and three temperatures. Clausius-Clapeyron equation used to calculate malagueta pepper seeds vaporization latent heat. From obtained results, it was concluded that temperature increase promotes malagueta pepper seeds moisture content reduction, in constant water activity. The Modified Oswin model properly adjusted to the experimental data, satisfactorily representing pepper seeds adsorption isotherms. The energy released during the adsorption process, represented by vaporization latent heat, increases with moisture content reduction, ranging from 2762.92 to $2495.56 \mathrm{~kJ} \mathrm{~kg}^{-1}$ for moisture contents from 0.056 to 0.134 (db).
\end{abstract}

Additional keywords: Capsicum frutescens L.; energy; hygroscopicity; seeds.

\section{Resumo}

Objetivou-se neste trabalho determinar e modelar as isotermas de adsorção das sementes de pimentamalagueta, assim como estimar o calor latente de vaporização liberado durante o processo de adsorção. Os teores de água de equilíbrio higroscópico foram determinados pelo método estático, utilizando seis soluções salinas e três temperaturas. A equação de Clausius-Clapeyron foi utilizada para calcular o calor latente de vaporização das sementes de pimenta-malagueta. A partir dos resultados obtidos, conclui-se que, em atividade de água constante, o aumento da temperatura promove a redução do teor de água das sementes de pimenta. O modelo de Oswin Modificado ajustou-se adequadamente aos dados experimentais, representando satisfatoriamente as isotermas de adsorção das sementes de pimenta. A energia liberada durante 0 processo de adsorção, representada pelo calor latente de vaporização, aumenta com a redução do teor de água, variando de 2.762,92 até $2.495,56 \mathrm{~kJ} \mathrm{~kg}^{-1}$ para os teores de água de 0,056 até 0,134 (b.s.).

Palavras-chave adicionais: Capsicum frutescens L.; energia; higroscopicidade; sementes.

\section{Introduction}

Capsicum genus belongs to the Solanaceae family, and has over 30 cultivated species in tropical and subtropical regions of the world (Yaldiz et al., 2010). Pepper berries vary in size, shape, flavor, color, pungency ( $\mathrm{Li}$ et al., 2011a), and chemical composition (Jarret et al., 2013). Such characteristics justify peppers and their seeds high consumption and use in food and nutrition, medicine, and cosmetics (Dagnoko et al., 2013).

Pepper seeds are considered by-products by food processing industries, since problems related to industrial waste are becoming increasingly common (Silva et al., 2013). Although being classified as industrial by-products ( $\mathrm{Li}$ et al., 2011a; Silva et al., 2013), studies have shown that Capsicum genus species seeds have promising chemical composition and biological activities for food and medicine use. Oils that are rich inhighly nutritious unsaturated fatty acids and linoleic acids (Embaby \& Mokhtar, 2011; Li et al., 2011a), crude fat sources, carbohydrates and some minerals (Embaby \& Mokhtar, 2011), antioxidant properties (Sim\& Sil, 2008), and tumor cells antiproliferative effects (Jeon et al., 2012) are associated with Capsicum genus species seeds.

As with many other agricultural products, in order to correctly dry and store pepper seeds, it is necessary to know the relation between the product and the surrounding air, temperature and relative humidity desirable for product quality conservation (Goneli et al., 2010; Corrêa et al., 2014). 
Pepper seeds, as well as other agricultural products, are hygroscopic, i.e., they have the capacity to give or absorb water from the environment, in order to reach their moisture content balance (Resende et al., 2006). Such phenomena are known as desorption and adsorption (Corrêa et al., 2014).

Agricultural products hygroscopic behavior may be analyzed through isothermal curves, or hygroscopic balance curves, which is the relation between a given product moisture content and water activity balance to a specific temperature (Resende et al., 2006; Clabera-Olivera et al., 2011; Al-Mahasneh et al., 2014).

Sorption isotherms are curves representing moisture content balance, through experimental data or empirical models. However, for a mathematical model to be properly used, certain physical properties knowledge is required (Stefanini \& Roa, 1980), such as vaporization latent heat, which is defined as the energy amount required to remove water from the product in desorption (Rodriguez-Arias et al., 1963; Corrêa et al., 1998); or the energy released by the product during adsorption (Wang \& Brennan, 1991).

Given agricultural products water sorption hygroscopicity and energy demand importance, the objective of this study was to obtain and model malagueta pepper seeds adsorption isotherms, as well as to determine product vaporization latent heat.

\section{Material and methods}

The study was conducted in the Agribusiness Food Laboratory of the Goiano Federal Institute of Education, Science and Technology - Campus Ceres, Goiás state. Malagueta pepper seeds (Capsicum frutescens L.) were used, which were manually extracted from berries harvested at the institution Experimental Sector.

After extraction, seeds were subjected to pre-drying, under laboratory conditions, for 48 hours. Subsequently, they were subjected to drying in an oven without forced ventilation, adjusted to provide a temperature of $70{ }^{\circ} \mathrm{C}$ for 48 hours, until achieving a moisture content of approximately 0.025 (db) (Goneli et al., 2010).

Hygroscopic balance moisture contents were determined using the static-gravimetric method for different controlled temperature conditions (30, 40 and $50^{\circ} \mathrm{C}$ ), being supplied by a drying oven, and water activity between 0.290 and 0.900 (decimal).

Samples, which contained approximately $1.0 \mathrm{~g}$ seeds, were placed in sorption recipients and put inside hermetic recipients containing saturated salt solutions (Ferreira et al., 2011; Silva \& Rodovalho, 2012).

Salt solutions were used to promote the different water activities shown in Table 1.

Table 1 -Saturated salt solutions water activity values ( $A_{w}$, decimal) (Greenspan, 1977).

\begin{tabular}{lcccccc}
\hline Solution $^{1}$ & $\mathrm{CaCl}$ & $\mathrm{Nal}$ & $\mathrm{NaNO}_{3}$ & $\mathrm{NaCl}$ & $\mathrm{KCl}$ & $\mathrm{MgSO}_{4}$ \\
\hline $\mathrm{A}_{w}$ & 0.290 & 0.362 & 0.731 & 0.751 & 0.836 & 0.900 \\
\hline
\end{tabular}

${ }^{1} \mathrm{CaCl}$ : Calcium chloride; Nal: Sodium iodide; $\mathrm{NaNO}_{3}$ : Sodium nitrate; $\mathrm{NaCl}$ : Sodium chloride; $\mathrm{KCl}$ : Potassium chloride; $\mathrm{MgSO}_{4}$ : Magnesium sulphate.

Periodically, samples were weighed on an analytical balance $(0.0001 \mathrm{~g})$ until reaching hygroscopic balance moisture content, i.e., until there was no weight change on three successive weighings (Ferreira et al., 2011; Sousa et al., 2013).

When reaching hygroscopic balance moisture content, it was determined using the oven method, at $105 \pm 3{ }^{\circ} \mathrm{C}$ for $24 \mathrm{~h}$, in three repetitions (Brasil, 2009).

Mathematical models that are often used to represent seeds and grains hygroscopic behavior were adjusted to the experimental data, and equations are shown in Table 2.

In order to adjust the mathematical models, non-linear regression analysis was carried out through Gauss Newton method. In order to check each model adjustment degree, regression coefficient significance was considered through t test, adopting $1 \%$ significance level. Determination coefficient $\left(R^{2}\right)$ magnitude and mean relative error values (P) were determined by Equation 21, and estimated average error (SE) was determined by Equation 22. For a good mathematical model adjustment, P must be lower than 10\% (Mohapatra \& Rao, 2005), and SE must be the nearest to zero.

$\mathrm{P}=\frac{100}{\mathrm{n}} \sum \frac{|\mathrm{Y}-\hat{\mathrm{Y}}|}{\mathrm{Y}}$

$\mathrm{SE}=\sqrt{\frac{\left(\mathrm{Y}-\hat{\mathrm{Y}}^{2}\right)}{\mathrm{GLR}}}$

Wherein: $Y$ - experimental value; $\hat{Y}$ - Value estimated by the model; $\mathrm{n}$ - number of experimental observations; GLR - model degrees of freedom (number of observations minus the number of model parameters).

Othmer et al. (1940), from Clausius-Clapeyron studies, proposed Equation 23 to measure steam partial pressure, which is contained in porous systems:

$\operatorname{Ln}(\mathrm{Pv})=\frac{\mathrm{L}}{\mathrm{L}^{\prime}} \cdot \operatorname{Ln}(\mathrm{Pvs})+\mathrm{C}$ 
Wherein: Pvs - free water saturation vapor pressure, for a given balance temperature $(\mathrm{T})$; $\mathrm{PV}$ - free water vapor pressure, in order to determine balance temperature $(\mathrm{T})$; $\mathrm{L}$ - product water vaporization latent heat, $\mathrm{kJ} \mathrm{kg}^{-1}$; $\mathrm{L}^{\prime}$ - free water vaporization latent heat, to the balance temperature, $\mathrm{kJ} \mathrm{kg}^{-1} ; \mathrm{C}$. integration constant.

In order to quantify Equation 23 LL'-1ratio values, which is the ratio of product water vaporization latent heat $(L)$ and free water latent heat $\left(L^{\prime}\right)$ values, in a pepper seeds hygroscopic balance moisture content and temperature range condition, methodology proposed by Stefanini \& Roa (1980) was used.
Water vaporization enthalpy equation, presented by Rodrigues-Arias, was adjusted to LL'-1 ratio values with the inclusion of a parameter in Equation 24, in order to improve LL'-1estimates (Corrêa et al., 1998):

$$
\frac{\mathrm{L}}{\mathrm{L}^{\prime}}-1=\mathrm{a} \cdot \exp \left(-\mathrm{b} \cdot \mathrm{X \textrm {e } ^ { \mathrm { m } }}\right)
$$

Balance temperature $\left({ }^{\circ} \mathrm{C}\right)$ free water vaporization latent heat $\left(\mathrm{kJ} \mathrm{kg}^{-1}\right)$ was calculated using the studied range mean temperature $(\mathrm{T})$, in ${ }^{\circ} \mathrm{C}$, using Equation 25:

$$
L^{\prime}=2502.2-2.39 \cdot T
$$

\begin{tabular}{|c|c|c|}
\hline Model Designation & Model & \\
\hline $\mathrm{Xe}^{*}=\frac{\left(\mathrm{Xm} \cdot \mathrm{c} \cdot \mathrm{a}_{\mathrm{w}}\right) \cdot\left(1-(\mathrm{n}+1) \cdot \mathrm{a}_{\mathrm{w}}{ }^{\mathrm{n}}+\mathrm{n} \cdot \mathrm{a}_{\mathrm{w}}{ }^{\mathrm{n}+1}\right)}{\left(1-\mathrm{a}_{\mathrm{w}}\right) \cdot\left[1+(\mathrm{c}-1) \cdot \mathrm{a}_{\mathrm{w}}-\mathrm{c} \cdot \mathrm{a}_{\mathrm{w}}{ }^{\mathrm{n}+1}\right]}$ & BET & (1) \\
\hline $\mathrm{Xe}^{*}=\left(\mathrm{a} \cdot \mathrm{b} \cdot \mathrm{a}_{\mathrm{w}}\right) /\left\{\left[1-\left(\mathrm{c} \cdot \mathrm{a}_{\mathrm{w}}\right)\right] \cdot\left[1+(\mathrm{b}-\mathrm{c}) \cdot \mathrm{a}_{\mathrm{w}}\right]\right\}$ & Modified BET & $(2)$ \\
\hline $\mathrm{Xe}^{*}=\left[\ln \left(1-\mathrm{a}_{\mathrm{w}}\right) /\left(-\mathrm{a} \cdot\left(\mathrm{T}^{\mathrm{b}}\right)\right)\right]^{1 / \mathrm{c}}$ & Cavalcante Mata & (3) \\
\hline $\mathrm{Xe}^{*}=\left[-1 /\left(\mathrm{c} \cdot \mathrm{T}^{\mathrm{d}}\right)\right] \cdot \ln \left[\ln \left(\mathrm{a}_{\mathrm{w}}\right) /\left(-\mathrm{a} \cdot \mathrm{T}^{\mathrm{b}}\right)\right]$ & Chen Clayton & (4) \\
\hline $\mathrm{Xe}^{*}=\mathrm{a}-\mathrm{b} \cdot \ln \left(-(\mathrm{T}+\mathrm{c}) \cdot \ln \left(\mathrm{a}_{\mathrm{w}}\right)\right]$ & Chung Pfost & (5) \\
\hline $\mathrm{Xe}^{*}=(-1 / \mathrm{b}) \cdot \ln \left[(\mathrm{T}+\mathrm{c}) \cdot \ln \left(\mathrm{a}_{\mathrm{w}}\right) /(-\mathrm{a})\right]$ & Modified Chung Pfost & (6) \\
\hline $\mathrm{Xe}^{*}=\exp \left[\mathrm{a}-(\mathrm{b} \cdot \mathrm{T})+\left(\mathrm{c} \cdot \mathrm{a}_{\mathrm{w}}\right)\right]$ & Copace & (7) \\
\hline $\mathrm{Xe}^{*}=1 /\left(\mathrm{a} \cdot \mathrm{T}^{\mathrm{b}}+\mathrm{a}_{\mathrm{w}}{ }^{\mathrm{c}}\right)$ & Corrêa & (8) \\
\hline $\mathrm{Xe}^{*}=\frac{\left(\mathrm{Xm} \cdot \mathrm{c} \cdot \mathrm{k} \cdot \mathrm{a}_{\mathrm{w}}\right)}{\left(1-\mathrm{c} \cdot \mathrm{a}_{\mathrm{w}}\right) \cdot\left(1-\mathrm{k} \cdot \mathrm{a}_{\mathrm{w}}+\mathrm{c} \cdot \mathrm{k} \cdot \mathrm{a}_{\mathrm{w}}\right)}$ & GAB & (9) \\
\hline $\mathrm{Xe}^{*}=\frac{\left[\mathrm{Xm} \cdot(\mathrm{c} / \mathrm{T}) \cdot \mathrm{k} \cdot \mathrm{a}_{\mathrm{w}}\right]}{\left(1-\mathrm{c} \cdot \mathrm{a}_{\mathrm{w}}\right) \cdot\left[\left(1-\mathrm{k} \cdot \mathrm{a}_{\mathrm{w}}+(\mathrm{c} / \mathrm{T}) \cdot \mathrm{k} \cdot \mathrm{a}_{\mathrm{w}}\right)\right]}$ & Modified GAB & $(10)$ \\
\hline $\mathrm{Xe}^{*}=\mathrm{Xm} \cdot\left[-\ln \left(\mathrm{a}_{\mathrm{w}}\right)\right]^{\mathrm{n}}$ & Halsey & (11) \\
\hline $\mathrm{Xe}^{*}=\left[\exp (\mathrm{a}-\mathrm{b} \cdot \mathrm{T}) /-\ln \left(\mathrm{a}_{\mathrm{w}}\right)\right]^{1 / \mathrm{c}}$ & Modified Halsey & (12) \\
\hline $\mathrm{Xe}^{*}=\left[\ln \left(1-\mathrm{a}_{\mathrm{w}}\right) /\left(-\mathrm{a} \cdot \mathrm{T}_{\mathrm{abs}}\right)\right]^{1 / \mathrm{c}}$ & Henderson & (13) \\
\hline $\mathrm{Xe}^{*}=\left\{\ln \left(1-\mathrm{a}_{\mathrm{w}}\right) /[-\mathrm{a} \cdot(\mathrm{T}+\mathrm{b})]\right\}^{1 / \mathrm{c}}$ & Modified Henderson & (14) \\
\hline $\mathrm{Xe} *=\mathrm{a} \cdot\left[\mathrm{a}_{\mathrm{w}} /\left(1-\mathrm{a}_{\mathrm{w}}\right)\right]^{\mathrm{b}}$ & Oswin & (15) \\
\hline$X e^{*}=(a+b \cdot T) /\left[a_{w} /\left(1-a_{w}\right)\right]^{1 / c}$ & Modified Oswin & $(16)$ \\
\hline $\mathrm{Xe}^{*}=\left[\left(\mathrm{a} \cdot \mathrm{a}_{\mathrm{w}}{ }^{\mathrm{b}}\right)+\left(\mathrm{c} \cdot \mathrm{a}_{\mathrm{w}}{ }^{\mathrm{d}}\right)\right]$ & Peleg & $(17)$ \\
\hline $\mathrm{Xe}^{*}=\mathrm{a} \cdot\left[\mathrm{a}_{\mathrm{w}}{ }^{\mathrm{b}} / \mathrm{T}^{\mathrm{c}}\right]$ & Sabbah & (18) \\
\hline $\mathrm{Xe}^{*}=\exp \left\{\mathrm{a}-(\mathrm{b} \cdot \mathrm{T})+\left[\mathrm{c} \cdot \exp \left(\mathrm{a}_{\mathrm{w}}\right)\right]\right\}$ & Sigma Copace & (19) \\
\hline$X e^{*}=a-(b \cdot T)-c \cdot \ln \left(1-a_{w}\right)$ & Smith & (20) \\
\hline
\end{tabular}

Table 2 - Mathematical models used to predict seeds and grains hygroscopic behavior.

Where: $\mathrm{Xe}{ }^{*}$ : balance moisture content, \% db; $\mathrm{a}_{\mathrm{w}}$; water activity, decimal; $\mathrm{T}$ : temperature, ${ }^{\circ} \mathrm{C} ; \mathrm{T}_{\mathrm{abs}}$ : absolute temperature; $\mathrm{Xm}$ : molecular monolayer moisture content, \% db; a, b, c, n, k: coefficients depending on the product. 
Free water saturation vapor pressure, Pvs, was calculated through Thétens equation (Equation 26):

$$
\text { Pvs }=0.61078 \cdot 10^{((7.5 \cdot T) /(273.3+\mathrm{T}))}
$$

Vapor pressure value $(\mathrm{Pv})$ was determined according to Equation 27:

$\mathrm{Pv}=\mathrm{a}_{\mathrm{w}} \cdot \mathrm{Pvs}$

In order to quantify pepper seeds water vaporization latent heat for each studied temperature, Equation 24 and Equation 25 were combined, giving Equation 28 (Corrêa et al., 1998):

$L=(2502.2-2.39 \cdot \mathrm{T}) \cdot\left[1+\mathrm{a} \cdot \exp \left(-\mathrm{b} \cdot \mathrm{Xe}^{\mathrm{m}}\right)\right]$

\section{Results and discussions}

Table 2 shows correlation coefficients, estimated average errors and average relative errors of mathematical models adjusted to malagueta pepper seeds hygroscopic balance moisture content, obtained by adsorption to different temperature and water activity conditions.

Table 2 -Determination coefficients $\left(R^{2}\right)$, estimated average errors (SE) and average relative errors $(P)$ of the different models adjusted to malagueta pepper seeds hygroscopic balance moisture content, for adsorption process.

\begin{tabular}{lrrr}
\hline \multirow{2}{*}{ Models } & $\mathrm{R}^{2}$ & $\mathrm{SE}$ & $\mathrm{P}$ \\
\cline { 2 - 3 } & \multicolumn{2}{c}{ (decimal) } & 12.5828 \\
\hline BET & 0.9239 & 1.8139 & 11.3995 \\
Modified BET & 0.9404 & 1.6125 & 9.7376 \\
Cavalcante Mata & 0.9594 & 1.3364 & 9.3940 \\
Chen Clayton & 0.9634 & 1.2839 & 9.6113 \\
Chung Pfost & 0.9606 & 1.3170 & 9.6113 \\
Modified Chung Pfost & 0.9606 & 1.3170 & 10.2715 \\
Copace & 0.9546 & 1.4115 & 10.5840 \\
Corrêa & 0.9529 & 1.4378 & 11.3992 \\
GAB & 0.9404 & 1.6125 & 10.9022 \\
Modified GAB & 0.9359 & 1.6698 & 12.0335 \\
Halsey & 0.9419 & 1.5765 & 8.8301 \\
Modified Halsey & 0.9713 & 1.1269 & 10.6751 \\
Henderson & 0.9430 & 1.5624 & 9.6292 \\
Modified Henderson & 0.9604 & 1.3210 & 11.2113 \\
Oswin & 0.9428 & 1.5654 & 8.5593 \\
Modified Oswin & 0.9730 & 1.0942 & 11.1069 \\
Peleg & 0.9451 & 1.5641 & 11.6208 \\
Sabbah & 0.9290 & 1.7542 & 9.7052 \\
Sigma Copace & 0.9645 & 1.2526 & 9.3004 \\
Smith & 0.9667 & 1.2135 & \\
\hline
\end{tabular}

It was noted that, among adjusted models, the highest values related to determination coefficient were observed for Modified Halsey $\left(R^{2}=0.9713\right)$ and Modified Oswin $\left(R^{2}=0.9730\right)$ models. Some authors stated that the determination coefficient should not be used alone in non-linear models selection (Goneli et al., 2010; Corrêa et al., 2014). Determination coefficient magnitude is not enough to assess hygroscopic balance models adjustment quality (Rosa et al., 2010).

Thus, in order to better assess models adjustment degree to the experimental data, estimated average error (SE) and average relative error (\% P) were determined, which are also shown in Table 2.

Regarding estimated average error (SE), it was observed in Table 2 that Modified Halsey $(\mathrm{SE}=1.1269)$ and Modified Oswin $(\mathrm{SE}=1.0942)$ models had the lowest values between the other studied models. According to Corrêa et al. (2014), the lowest SE value indicates best model adjustment to the experimental data.

For a non-linear model to be used in hygroscopic phenomena representation, the average relative error should be lower than 10\% (Rosa et al., 2010). Thus, it is verified in Table 2 that, among adjusted models, Modified Halsey ( $P=8.8301 \%)$ and Modified Oswin ( $P=8.5593 \%)$ also had the best statistical adjustments.

Table 3 shows Modified Halsey and Modified Oswin model coefficients that were significant at $1 \%$ probability by test, thus proving these models suitability in the studied phenomenon description. 
Table 3 - Modified Halsey and Modified Oswin model coefficients adjusted to malagueta pepper seeds hygroscopic balance moisture contents.

\begin{tabular}{lrcc}
\hline \multirow{2}{*}{ Models } & \multicolumn{3}{c}{ Coefficients } \\
\cline { 2 - 4 } & $\mathrm{a}$ & $\mathrm{b}$ & $\mathrm{c}$ \\
\hline Modified Halsey & $5.5847^{* *}$ & $0.0239^{* *}$ & $2.3355^{* *}$ \\
Modified Oswin & $12.2714^{* *}$ & $-0.0912^{* *}$ & $2.8304^{* *}$ \\
\hline
\end{tabular}

${ }^{\star *}$ Significant at 0.01 by $t$ test.

Based on the evaluated statistical parameters (Table 2 and 3 ), and due to being a simple equation that adequately describes many biological products sorption isotherms (Chen, 1990), the Modified Oswin
Model was selected to estimate hygroscopic balance moisture contents and to describe adsorption isotherms of malagueta pepper seeds (Figure 1).

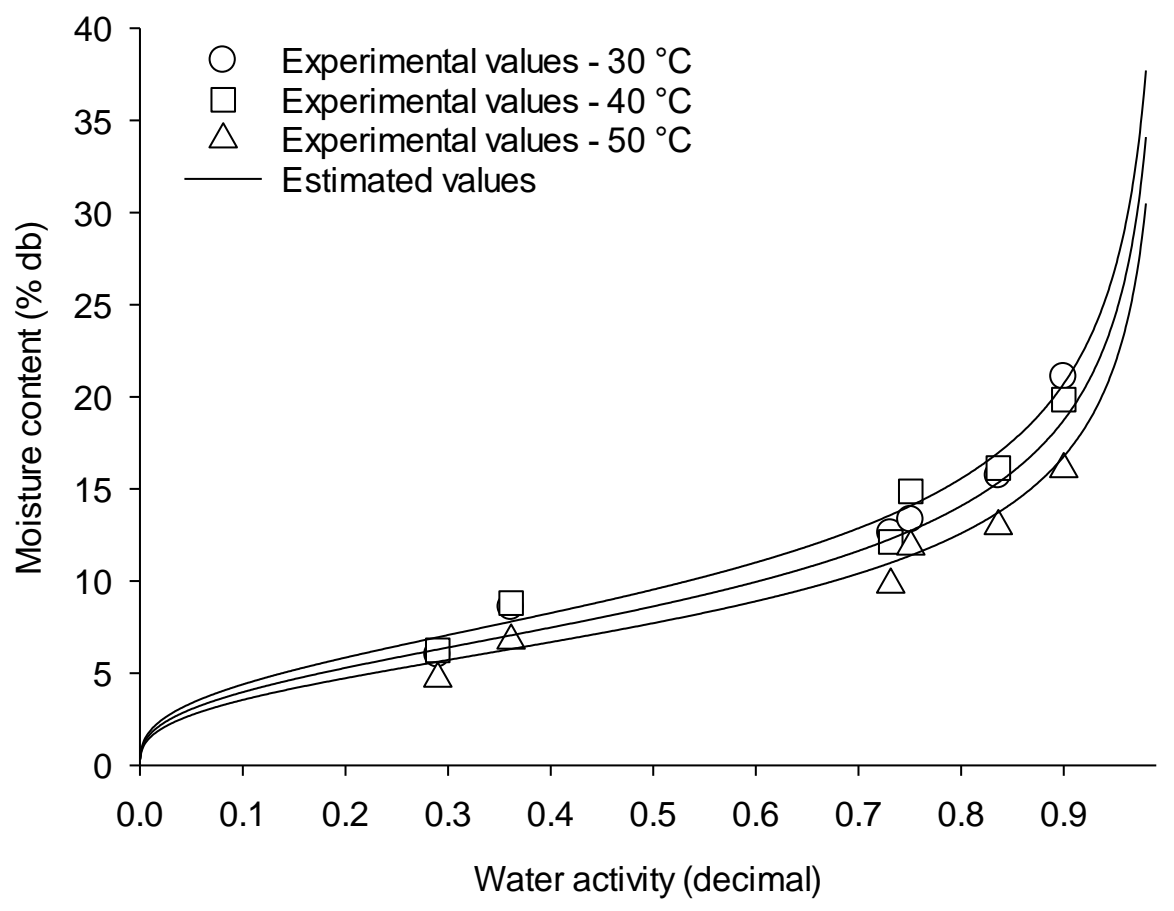

Figure 1 - Malagueta pepper seeds hygroscopic balance moisture content and adsorption isotherms experimental values, estimated by the Modified Oswin model, and obtained for the different temperature and water activity conditions.

In studies with yellow cumarí seeds (Capsicum chinense), Ferreira et al. (2011) also recommended the modified Oswin model to estimate hygroscopic balance moisture content for the activity range of 0.29 to 0.9 (decimal), and for temperature between 30 and $40{ }^{\circ} \mathrm{C}$. This same model satisfactorily represented wheat seeds ( $\mathrm{Li}$ et al., 2011b), corn grains (Smaniotto et al., 2012), crambe fruits (Costa et al., 2013), forage turnip seeds (Sousa et al., 2013), linseeds (Singh \& Kumari, 2014), and husked rice seeds (Oliveira et al., 2014a) hygroscopicity.

Looking at Figure 1, it is observed that, for constant water activity, temperature increase caused seeds moisture content reduction. According to Al-Muhtaseb et al. (2004), temperature effect on isothermal absorption is very important, since food are exposed to a range of temperatures during the post-harvest stage.

This behavior was already expected, since the water vapor pressure in the air and on seeds surface is directly proportional to temperature. Furthermore, as seeds have a higher number of water molecules than air, higher product surface water vapor pressure is observed, what means higher water loss for the product to reach hygroscopic balance (Ferreira \& Pena, 2003).

It was observed in Figure 1 that malagueta pepper seeds adsorption isotherms estimated by Modified Oswin model have a characteristic sigmoidal shape of type II curves, according to BET classification (Brunauer et al., 1938). This format is considered standard for agricultural products. 
Figure 2 shows experimental and estimated values of pepper seeds water vaporization latent heat and free water vaporization latent heat ratio $\left(L^{\prime \prime-1}\right)$, as a function of pepper seeds moisture content.

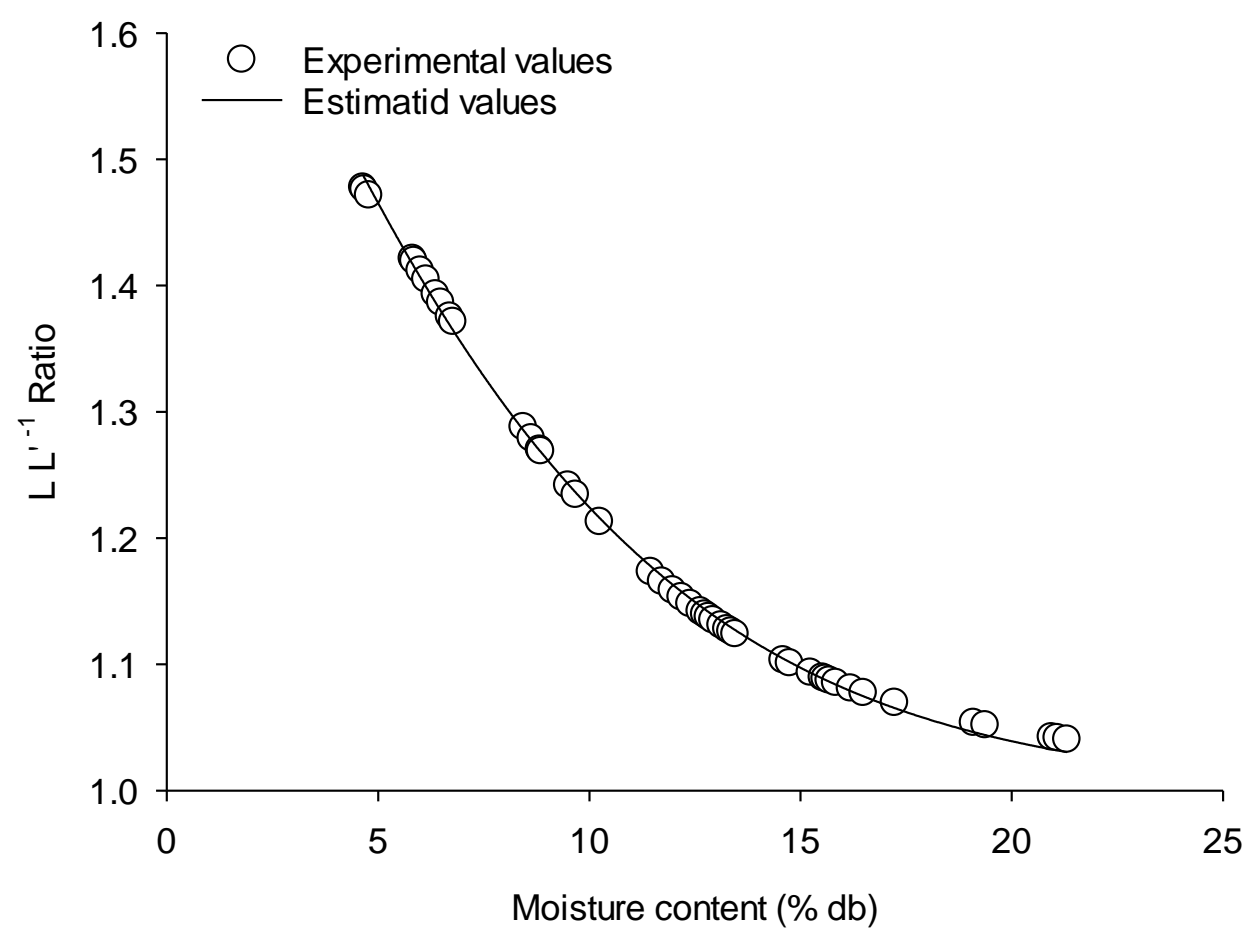

Figure 2 - LL'-1 ratio experimental and estimated values, as a function of malagueta pepper seeds water balance contents.

It was noted that the $L^{\prime} L^{\prime-1}$ ratio is indirectly proportional to seeds moisture content, moisture content reduction promotes $L^{\prime} L^{\prime-1}$ ratio increase. In addition, it was observed that all $L^{\prime \prime-1}$ ratio values were higher than 1 , demonstrating that the energy released by seeds to absorb water during the adsorption process is always higher than the energy needed to evaporate pure water. Similar behaviors were observed for coffee beans and soybean
(Stefanini \& Roa, 1980), popcorn seeds (Corrêa et al., 1998), husked red rice grains (Rodovalho et al., 2009), wheat seeds (LI et al., 2011b), yellow cumarí seeds (Ferreira et al., 2011), castor beans (Ojediran et al., 2013), and tucumã-de-Goiás seeds (Oliveira et al., 2014b).

Table 4 shows Equation 24 "a", "b", and "m" coefficients adjusted to $L L^{\prime-1}$ ratio experimental data.

Table 4 - Coefficients used to calculate malagueta pepper seeds $L^{\prime-1}$ ratio.

\begin{tabular}{cccc}
\hline $\mathrm{a}$ & $\mathrm{b}$ & $\mathrm{m}$ & $\mathrm{R}^{2}$ \\
\hline $0.7855^{\star \star}$ & $0.0690^{* \star}$ & $1.2594^{\star *}$ & 0.9993 \\
\hline
\end{tabular}

** Significant to 0.01 by $t$ test.

It was observed in Table 4 that Equation 24 was properly adjusted to $L^{L^{\prime}-1}$ ratio experimental data, since it showed high determination coefficient $\left(R^{2}=0.9993\right)$ and significant coefficients at $1 \%$ probability by $\mathrm{t}$ test. Thus, it can be used to determine pepper seeds water vaporization latent heat.

Substituting Table 4 coefficient values in the equation proposed by Corrêa et al. (1998), and adding free water vaporization latent heat, there is
Equation 29, which was used to calculate pepper seeds water vaporization latent heat for each temperature.

$L=(2502.2-2.39 T)\left[1+0.7855 \exp \left(-0.690 \times e^{1.2594}\right)\right](29)$

In Figure 3, water vaporization latent heat curves are shown, as a function of malagueta pepper seeds moisture contents for the three studied temperatures. 


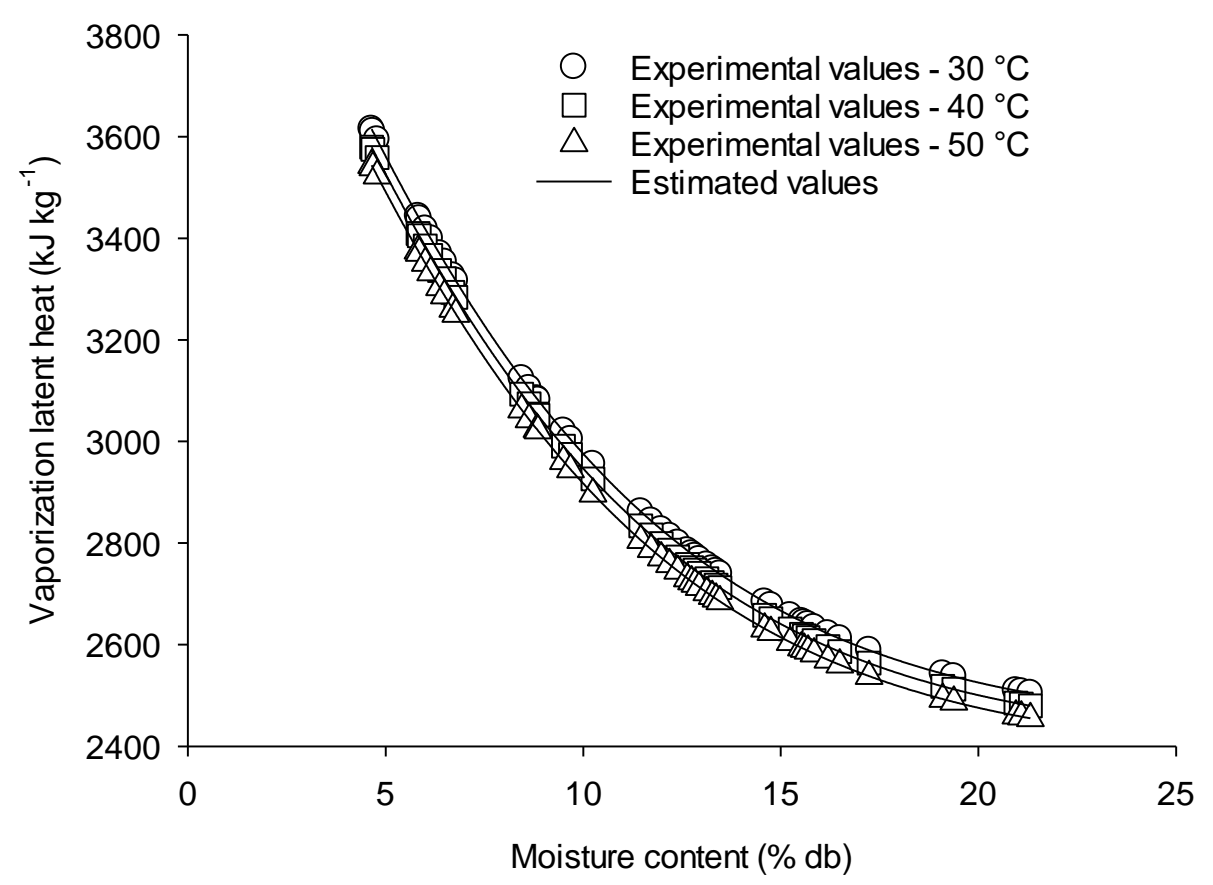

Figure 3 - Malagueta pepper seeds water vaporization latent heat curvesfor different temperatures.

It was noted that seeds water vaporization latent heat values increase with moisture content decrease. Moreover, it was verified that for the same moisture content, temperature increase caused vaporization latent heat reduction. Ferreira et al. (2011), Smaniotto et al. (2012), and Oliveira et al. (2014b), in studies with yellow cumarí seeds, corn grains, and tucumã-de-Goiás seeds, respectively, found similar behavior to that observed in this study.

According to Wang \& Brennan (1991), water vaporization latent heat released during adsorption is an indicator of intermolecular attraction forces between the product water vapor adsorption sites. Thus, it can be seen in Figure 2 that the moisture content close to $0.21 \mathrm{~L}$ value for malagueta pepper seeds are of $2504.4 \mathrm{~kJ} \mathrm{~kg}^{-1}$ at $30{ }^{\circ} \mathrm{C}, 2479.8 \mathrm{~kJ} \mathrm{~kg}^{-1}$ at $40{ }^{\circ} \mathrm{C}$, and $2455.1 \mathrm{~kJ} \mathrm{~kg}^{-1}$ at $50{ }^{\circ} \mathrm{C}$. These $\mathrm{L}$ values are close to the L' value (2406.6 $\left.\mathrm{kJ} \mathrm{kg}^{-1}\right)$, indicating water molecules existence in the free form, with reduced attraction forces.

Pepper seeds water vaporization latent heat values, with moisture content in the range of 0.046 to $0.213(\mathrm{db})$, varied from 3615.01 to $2455.14 \mathrm{~kJ} \mathrm{~kg}^{-1}$. In studies with corn grains in the moisture content range from 0.127 to $0.233(\mathrm{db})$, Smaniotto et al. (2012) found that vaporization latent heat varied from 2775.87 to $2468.14 \mathrm{~kJ} \mathrm{~kg}^{-1}$. Oliveira et al. (2014c) found that, for purging nut seeds with moisture content in the range from 0.056 to $0.134(\mathrm{db})$, vaporization latent heat ranged from 2762.92 to $2495.56 \mathrm{~kJ} \mathrm{~kg}^{-1}$.

Differences in each product vaporization latent heat can be attributed to characteristics and factors related to them (Resende et al., 2006), such as moisture content, temperature (Brooker et al., 1992), and chemical composition.

\section{Conclusions}

In constant water activity, malagueta pepper seeds hygroscopic balance moisture content decreases with increasing temperature.

Modified Halsey and Modified Oswin models are the best to represent pepper seeds adsorption isotherms in the studied conditions.

Isotherm curves have a characteristic type II sigmoidal shape, which is common for most agricultural products.

Through moisture content reduction, there was increased energy released by seeds during water adsorption, and pepper seeds water vaporization latent heat values, in the moisture content range from 0.046 to $0.213(\mathrm{db})$, varied from 3615.01 to $2455.14 \mathrm{~kJ} \mathrm{~kg}^{-1}$.

\section{References}

Al-Muhtaseb AH, McMinn WAM, Magee TRA (2004) Water sorption isotherms of starch powders. Part 1 : mathematical description of experimental data. Journal of Food Engineering 61(3):297-307.

Al-Mahasneh M, Alkoaik F, Khalil A, Al-Mahasneh A, El-Waziry A, Fulleros R, Rababah T (2014) A generic method for determining moisture sorption isotherms of cereal grains and legumes using artificial neural networks. Journal of Food Process Engineering 38(3):308-316 . 
Brasil. Ministério da Agricultura e Reforma Agrária (2009). Regras para análise de sementes / Ministério da Agricultura Pecuária e Abastecimento. Secretaria Nacional de Defesa Agropecuária. Brasília: MAPA/ACS. 399p.

Brooker DB, Bakker-Arkema FW, Hall CW (1992) Drying and storage of grains and oilseeds. Westport: AVI Publishing Company. 450p.

Brunauer S, Emmett PH, Teller E (1938) Adsorption of gases in multimolecular layer. Journal of American Chemistry Society 60(1):309-312.

Chen CC (1990) Modification of Oswin EMC/ERH equation. Journal of Agriculture Research China 39(4):367-376.

Clabera-Olivera F, Marczak LDF, Noreña CPZ, Pettermann AC (2011) Modeling water adsorption of pinhão (Araucaria angustifolia seed) flour and thermodynamic analysis of the adsorption process. Journal of Food Process Engineering 34(3):826-843.

Corrêa PC, Christ D, Martins JH, Mantovani BHM (1998) Curvas de dessorção e calor latente de vaporização para as sementes de milho pipoca (Zea mays). Revista Brasileira de Engenharia Agrícola e Ambiental 2(1):7-11.

Corrêa PC, Botelho FM, Botelho SCC, Goneli ALD (2014) Isotermas de sorção de água de frutos de Coffea canephora. Revista Brasileira de Engenharia Agrícola e Ambiental 18(10):1047-1052.

Costa LM, Resende O, Oliveira DEC (2013) Isotermas de dessorção e calor isostérico dos frutos de crambe. Revista Brasileira de Engenharia Agrícola e Ambiental 17(4):412-418.

Dagnoko S, Yaro-Diarisso N, Sanogo PN, Adetula O, Dolo-Nantoumé A, Gamby-Tourpé K, Traoré-Théra A, Katilé S, Diallo-Ba D (2013) Overview of pepper (Capsicum spp.) breeding in West Africa. African Journal of Agricultural Research 8(13):1108-1114.

Embaby HES, Mokhtar SM (2011) Chemical composition and nutritive value of lantana and sweet pepper seeds and nabak seed kernels. Journal of Food Science 76(5):736-741.

Ferreira CD, Pena RS (2003) Comportamento higroscópico da farinha de pupunha (Bactris gasipaes). Ciência e Tecnologia de Alimentos 23(2):251-255.

Ferreira SCS, Silva HW, Rodovalho RS (2011) Isotermas de dessorção e calor latente de vaporização da semente de pimenta cumari amarela (Capsicum chinense L.). Revista Liberato 13(18):1-16.
Goneli ALD, Corrêa PC, Oliveira GHH, Gomes CF, Botelho FM (2010) Water sorption isotherms and thermodynamic properties of pearl millet grain. International Journal of Food Science and Technology 45(2):282-383.

Greenspan L (1977) Humidity fixed points of binary saturated aqueous solutions. Journal of Research of the National Bureau of Standards - A. Physics and Chemistry 81a(1):89-96.

Jarret RL, Levy IJ, Potter TL, Cermak SC (2013) Seed oil and fatty acid composition if Capsicum spp. Journal of Food Composition and Analysis 30(2):102-108.

Jeon G, Choi Y, Lee SM, Kim Y, Oh M, Jeong HS, Lee $J$ (2012) Antioxidant and antiproliferative properties of hot pepper (Capsicum annuum L.) seeds. Journal of Food Biochemistry 36(5):595-603.

Li G, Song C, You J, Sun Z, Xia L, Suo Y (2011a) Optimization of red pepper seed oil extraction using supercritical $\mathrm{CO}_{2}$ and analysis of the composition by reversed-phase HPLC-FLD-MS/MS. International Journal of Food Science and Technology 46(1):44-51.

Li X, Cao Z, Wei Z, Feng Q, Wang J (2011b) Equilibrium moisture content and sorption isosteric heats of five wheat varieties in China. Journal of Stored Products Research 47(1):39-47.

Mohapatra D, Rao PS (2005) A thin layer drying model of parboiled wheat. Journal of Food Engineering 66(4):513-18.

Ojediran J, Raji AO, Owamah HI (2013) Isosteric heats of water vapor sorption in two castor varieties. Journal chemical Engineering and Process Technology 4(2):1-6.

Oliveira DEC, Resende O, Campos RC, Donadon JR (2014a) Obtenção e modelagem das isotermas de dessorção e do calor isostérico para sementes de arroz em casca. Científica 42(3):203-210.

Oliveira DEC, Resende O, Campos RC, Sousa KA (2014b) Propriedades termodinâmicas de sementes de tucumã-de-Goiás (Astrocaryum huaimi Mart.). Revista Caatinga 27(3):53-62.

Oliveira DEC, Resende O, Chaves TH, Sousa KA, Smaniotto TAS (2014c) Propriedades termodinâmicas das sementes de pinhão-manso. Bioscience Journal 30(suplemento 1):147-157.

Othmer DF (1940) Correlation vapor pressure and latent heat data: A new plot. Industrial and Engineering Chemistry, Washington, v.32, n.6, 1940.

Resende O, Corrêa PC, Goneli ALD, Ribeiro DM (2006) Isotermas e calor isostérico de sorção do feijão. Ciência e Tecnologia dos Alimentos 26(3):626-631. 
Rodovalho RS, Devilla IA, Ascheri DPR, Bassinello PZ, Ferreira DA (2009) Isotermas de sorção do arrozvermelho em casca (Oriza sativa L.) Revista Brasileira de Armazenamento 34(2):144-152.

Rodriguez-Arias JH, Hall CW, Bakker-Arkema FW (1963) Heat of vaporization for shelled corn. Agricultural Engineering 40:677-683.

Rosa GS, Moraes MA, Pinto LAA (2010) Moisture sorption properties of chitosan. Food Science and Technology 43(3):415-420.

Silva HW, Rodovalho RS (2012) Isotermas de dessorção das sementes de pimenta malagueta. Global Science and Technology 5(1):32-39.

Silva LR, Azevedo J, Pereira MJ, Valentão P, Andrade PB (2013) Chemical assessment and antioxidante capacity of pepper (Capsicum annuum L.) seeds. Food and Chemical Toxicology 53(1):240248, 2013.

Sim KH, Sil HY (2008) Antioxidant activities of red pepper (Capsicum annuum) pericarp and seed extracts. International Journal of Food Science and Technology 43(10):1813-1823.
Singh AK, Kumari N (2014) Moisture sorption isotherms characteristics of ground flaxseed. Journal Food Process Technology 5(4):1-3.

Smaniotto TAS, Resende O, Oliveira DEC, Sousa $\mathrm{KA}$, Campos RC (2012) Isotermas e calor latente de dessorção dos grãos de milho da cultivar AG 7088 . Revista Brasileira de Milho e Sorgo 11(3):312-322.

Sousa KA, Resende O, Costa LM (2013) Isotermas de dessorção das sementes de nabo forrageiro obtidas pelos métodos dinâmico e estático. Revista Brasileira de Engenharia Agrícola e Ambiental 17(2):216-222.

Stefanini R, Roa G (1980) Algorítmo geral para determinação do calor latente de vaporização da água dos produtos biológicos. Revista Brasileira de Armazenamento 5(1):30-42.

Wang N, Brennan JG (1991) Moisture sorption isotherms characteristics of potatoes at four temperatures. Journal of Food Engineering 14(1)269-287.

Yaldiz G, Ozguven M, Sekeroglu N (2010) Variation in capsaicin contents of different Capsicum species and lines by varying drying parameters. Industrial Crops and Products 32(3):434-438. 